\title{
BENDA Mihály
}

Magyar Tudományos Akadémia

Bölcsészettudományi Kutatóközpont

Irodalomtudományi Intézet

Budapest, Magyarország

benda.mihaly@btk.mta.hu

\section{EGY MAGYAR KÓSZÁLÓ FRANCIAORSZÁGI ÚTLEÍRÁSA}

A töredékesség és a mozaikszerüség Illyés Gyula

Franciaországi változatok címü müvében

\section{Account of a Hungarian Wanderer's Journey in France \\ Fragmentariness and mosaic features in the work \\ French Variations by Gyula Illyés}

\author{
Putopis po Francuskoj jednog Mađara, lutalice \\ Fragmentarnost i mozaičnost $u$ delu \\ Francuske varijante Đule Ileša
}

1947-ben Illyés Gyula kétszer járt Franciaországban. Az év elején öt hetet töltött Párizsban, majd novemberben Dél-Franciaországba utazott. A két utazását útirajzban is megörökítette. Tanulmányom a párizsi út leírásával és a Franciaországi változatokkal foglalkozik. Az útleírás jellegzetessége, hogy mozaikszerü és eltérő stílusú szövegek gyüjteménye: keveredik benne az esszé és a tényleges útleírás, amelyeknek nagy része sétáló leírás. A mü időstruktúrája is szaggatott, illetve az elbeszélés idejében sok az ellipszis, a kihagyás. Az egész útleírást áthatja a kószáló esztétikája. A sétáló leírás és a sétáló figurája a XIX. század során válik népszerűvé, amikor megjelenik egy új „táj” is, a város. Illyés művében nemcsak sétáló leírásokat találunk, de művének szaggatott formája a kihagyásokkal is megjeleníti a sétálást. Így a mủ nemcsak tartalmi szinten, hanem formájában is színpadra állítja a sétálás aktusát.

Kulcsszavak: Illyés Gyula, Franciaország, kószáló esszé, diszkontinuitás, töredékesség 
Illyés Gyula 1947-ben kétszer is járt Franciaországban. Az év elején öt hetet töltött Párizsban, majd novemberben Dél-Franciaországba utazott. A két utazását útirajzban is megörökítette. Az első könyv alakban is megjelent Franciaországi változatok címen 1947-ben, a másik csak a Szíves kalauz címü útijegyzet gyüjteményben Egy falu Dél-Franciaországban címmel. A két szöveg között sok a formai hasonlóság. Mindkét müre jellemző a töredékesség, „mozaikszerủen” építkeznek, és jellemzőjük a diszkontinuitás. Tanulmányom célja, hogy bemutassam Illyés Franciaországi változatok címü müve mozaikszerüségének a kapcsolatát a nagyvárosi sétáló figurájával és esztétikájával.

Illyés párizsi utazását néhány hetes svájci pihenés elözte meg, amelyet a Comité International pour le Placement des Intellectuels Réfugiés, a genfi magyar könyvtár vezetőjeként tevékenykedő Hubay Miklós tett lehetővé a magyar írónak. Illyés mellett Márai Sándor, Cs. Szabó László, Czóbel Béla, Ferenczy Béni, Pátzay Pál, Szőnyi István és Szüts László is a meghívottak között volt. A svájci tartózkodás után Illyés Cs. Szabó társaságában meglátogatta a Brissagóban élő emigráns filozófust, Babits Mihály egykori barátját, Szilasi Vilmost, majd Rómában a Magyar Intézet vendégszeretetét élvezte. Végül mind a ketten Párizsba utaztak (Németh 2015, 143-144).

A Franciaországi változatokat a kortárs kritika útirajzként olvasta, ugyanakkor észrevette a mü töredezettségét. Fiers Tamás recenziójában többször is képekként jellemez egyes fejezeteket (Fiers 1947, 375-376), Keszi Imre pedig „,naplószerü jegyzetekről” beszél (Keszi 1947, 4). A könyv címe is a jegyzetszerüséget sugallja, mintha azt mondaná, változatok Franciaországra. Az útleírásban is hiába keressük az összefüggő narratívát. A mú sokkal inkább Párizzsal kapcsolatos képek sora, amelyet keretbe foglal $A$ vámos címủ nyitóés a Búcsú a várostól címü zárófejezet, amelyek a megérkezést és a távozást tematizálják, így kötve a könyvet az útleírás múfajához. Minden fejezet külön címet kapott, és a részek eltérő hosszúságúak. Az utazás értelme címü mindössze négy-, a Bukás után pedig ötsoros, ami szintén a mü mozaikszerüségére hívja fel a figyelmet. Ráadásul az egyik fejezet a Kószálás közben címet viseli.

Általánosan elfogadott, hogy a kószálás (legalábbis a kortárs kulturális elméletben használt kifejezés) a XIX. század közepén a városi modernitás kontextusában jött létre. Walter Benjamin német filozófus hívta fel a figyelmet a kószáló (flâneur) figurájának a fontosságára és súlyára Baudelaire életművében, és azóta mitologikus alakká vált. A kószáló figuráját Benjamin elképzelése szerint az átalakuló nagyváros hívta életre. Szerinte a „passzázsok nélkül a városi kószálás nem válhatott volna olyan jelentőssé" (Benjamin 1980, 852). A Második Császárság (1852-1870) korában, III. Napóleon uralkodása alatt 
Párizs modern nagyvárossá vált. Az uralkodó 1853-ban átadta a várost Haussmann bárónak, aki rövid idő alatt felszámolta a szük utcákat meg a félig elzárt árkádokat, és a helyükre széles sugárutakat és hatalmas áruházakat építtetett. Az új városszerkezet nemcsak a kormányzati ellenőrzést segítette elö, hanem az emberek szabad mozgását is. Ily módon Párizs utcái rengeteg ember számára váltak hozzáférhetőkké. A kivilágított járdák biztonságossá tették a közlekedést, a nagy áruházak kirakatai és a sok látnivaló rengeteg embert vonzott az utcákra. A város új képe könnyebbé tette a közéletet, és fokozta a fogyasztást.

Walter Benjamin Baudelaire-írásai óta a kószálót a XIX. századi város jellemző alakjaként tartjuk számon. Van azonban némi vita a kószáló (flâneur) megjelenési időpontja körül. Priscilla Parkhurst Ferguson szerint már a XIX. század elején megjelenik, vagyis körülbelül negyven évvel korábban, mint ahogy a legtöbb irodalomtörténész datálta. ${ }^{1}$ Ferguson úgy gondolja, hogy Balzac testesíti meg a korai flâneur alakját (Ferguson 2015, 28). Anke Gleber szerint a flâneur korai alakja található meg a XIX. századi utazási naplókban (például Heinrich von Kleistnél), és az 1830-1840-es párizsi vándorok leírásaiban is (Gleber 1999, 7-8). Mazlish még korábbra helyezi a kószáló ősét, szerinte a XVIII. századi „objektív szemlélődo”” testesíti meg az elődjét. Szerinte Adam Smith is egy korai kószálónak tekinthető (Mazlish 2015, 43-60).

Sokan Louis-Sébastien Mercier-t tartják az 1830-1840-es évek kószálója legjelentősebb elődjének. ${ }^{2}$ Mercier vázlatok százait készítette a kortársairól és tette közzé hihetetlenül népszerü, 1781 és 1788 között íródott Tableau de Paris (Párizsi képek) címü könyvében. A francia író úgy gondolta, hogy a párizsi életet bemutató munkáját a „lábával festette”(Mercier 1994, 1309). Könyvének előszavában számos vonását fedezhetjük fel a XIX. századi sétálónak: hangsúlyozza a megfigyelés fontosságát, és nagy jelentőséget tulajdonít a jelen Párizs és a párizsiak ismeretének, szemben a múlt városának az alakjaival:

\footnotetext{
Lásd Ferguson, Priscilla Parkhurst. 1993. The Flaneur and the Production of Culture. In Cultural Participation: Trends Since the Middle Age, szerk. Rigney, Ann-Fokkema, Douwe W. 109-124. Amsterdam-Philadelphia: John Benjamins Publishing; Ferguson, Priscilla Parkhurst. 1994. Paris as revolution. Berkeley-Los Angeles-London: University of California Press; Ferguson, Priscilla Parkhurst. 2015. The flâneur on and off the streets of Paris. In The flaneur, szerk. Keith Tester. 22-42. London-New York: Routledge.

2 Lásd Stierle, Karlheinz. 2001. La Capitale des signes: Paris et son discours. Ford. RocherJacquin, Marianne. Paris: Editions de la Maison des Sciences de l'Homme; Ferguson, Priscilla Parkhurst. 1994. Paris as revolution. Berkeley-Los Angeles-London: University of California Press; Montandon, Alain. 2000. Sociopoétique de la promenade. Clermond-Ferrand: Presses Universitaires Blaise Pascal-Maison de la Recherche.
} 
Sok lakója idegenként él a városban. [...] Ők nem vesznek észre már semmit, mivel azokat a tárgyakat, amelyeket minden nap látunk, nem azok, amelyeket a legjobban ismerünk. [...] Ami körülöttem van, azt lehet a legjobban megfigyelni. A látható dolgok között kell élni, és nem Spártában, Rómában, Athénban sétálni. Kedves kortársaim és honfitársaim, íme a személy, akit meg akarok ismerni (Mercier 1994, 5, 11).

Karlheinz Stierle szerint Louis-Sébastien Mercier életében a városnak szemiotikai funkciója volt: a város minden részlete jellé vált, amelynek segítségével megérthetjük a főváros rejtett valóságát. A város így egy vastag könyv, amely magába süríti „a lehetséges tapasztalatok teljességét” (Stierle 2001, 3). Ebből kifolyólag az író nem csupán leírja a környezetét, de egy rejtjeles írás olvasója. Mercier vállalkozása abban különbözik a két kortársának, Hurtaut-nak és Magny-nak a vállalkozásától, hogy nem kíván egy katalógust vagy leltárt készíteni (Mercier 1994, 14). Ö kijelenti, hogy arról akar beszélni, ami megragadja a város őrült vagy észszerü, de mindig változó sokaságából (Mercier 1994, 13). Mercier-nél a város ,egy mélyreható, még nem feltárt részleteknek, megfigyelésnek a tárgya" (Stierle 2001,3).

Hiba lenne azt állítani, hogy Mercier az egyedüli a XVIII. század végén, akinél tetten érhetjük a városnak az új érzékelését. Rétif de la Bretonne Párizsi éjjelek címü könyve szintén egy sétáló szemszögéből mutatja be a francia fővárost. Michel Delon Louis Sébastien Mercier és Rétif de la Bretonne írásait tartalmazó könyv előszavában a két író hasonlóságáról beszél, és „közvetlen írásos beszámolóként" (Delon 1990, VII) jellemzi a könyveiket, amelyek nem hierarchizálják a stílusokat és a témákat (Delon 1990, VIII). Mindkét írónak ugyanaz a célja: bebarangolni Párizs utcáit meglepő téma után kutatva, amely segít abban, hogy megértsük a főváros társadalmi müködését.

Mercier, miközben nagy gondot fordít arra, hogy minél pontosabban és lendületesebben mutassa be a városi lét mindennapjait, folyamatosan tematizálja a tekintetet és a nézés tevékenységét is. Könyvében arról biztosítja olvasóját, hogy arról fog beszélni, amit ténylegesen látott. Összekapcsolja a látás adottságát a városban történő helyváltoztatással, és magát sétáló megfigyelőként aposztrofálja:

Annyit futottam, hogy elkészüljön a Tableau de Paris, hogy azt lehet mondani, a lábammal csináltam. De megtanultam lassan járni a főváros kövezetén, meg gyorsan és fürgén. Ez egy olyan titok, ami nélkülözhetetlen ahhoz, hogy mindent lássunk. A feladat, hogy ne járjunk lassan, mert valaki várakozik (Mercier 1994, 1309). 
Mercier nemcsak egy képet akar adni korának városáról, de írásának formai megoldásaival imitálja a jelen mulandóságát. A francia író átkutatja a várost, és egymást követő rövid fejezetekben bemutatja azt. Ezek a fejezetek minden rendszer nélkül követik egymást. Ez a fragmentált írásmód képes egyedül bemutatni a városi utcai élet mulandóságát és gyors változékonyságát. Mercier könyvének néhány fejezete ennél is töredékesebb, és nem egy témát jár körül, hanem több különböző megfigyelés követi egymást úgy, hogy bármilyen kapcsolódás lenne közöttük. Ezt látjuk a Megjegyzések címü (CLXXVII. számú) fejezetben:

Vannak olyan párizsi nők, akik csak este kelnek fel, és hajnalban fekszenek le; egy szép lelkủ nő ezt a szokást követi, és lámpának hívják. A háziasszony nem beszél egyáltalán az ételekröl, amelyek az asztalon vannak; csak a rennes-i jércét, mans-i foglyot és a périgueux-i pástétomot, a ganges-i birkát és a spanyol olívabogyót jelentheti be. Ha a nap hősei akarunk lenni, a testalkat, a szellem és az érzések finomságát kell birtokolnunk (Mercier 1994, 419-420).

A szerző ilyen megoldásait olvasva az olvasónak az az érzése támad, hogy odavetett jegyzeteket olvas. Ráadásul a Párizsi képek címü könyvben sem a kronologikus sorrend, sem a földrajzi elrendezés nem érvényesül. Így szakít azzal az arisztotelészi tradícióval, mely szerint egy irodalmi alkotásnak legyen eleje, közepe és vége. Karlheinz Stierle szerint a Párizsi képek fragmentált ábrázolása elkap egy pillanatot, egy apró gesztust, egy részletét és egy oldalát a városnak. Szerinte ez az ábrázolás a szétszórt érzékelésből fakad, amely a város valóságának a kaleidoszkópját alkotja meg, ahol az olvasó ugyanúgy megélheti a mindig új megjelenés kalandját (Stierle 2001, 92).

Joanna Stalnaker Karlheinz Stierléhez hasonlóan úgy gondolja, hogy a fejezetek tetszőleges sorrendben olvashatóak, éppúgy, ahogy egy várost is bármilyen módon bejárhatunk: „Mivel a fejezetek rövidek, leíró címmel rendelkeznek, és nehezen megkülönböztethetö sorrendben vannak elrendezve, az olvasónak olyan szabadságot biztosítanak, hogy a szövegben úgy sétálhasson, ahogy magának Mercier-nek kellett sétálnia a városban" (Stalnaker 2006, 224).

Mercier fejezeteit töredékes szövegeknek tekinthetjük, amilyeneket majd a német romantikusok írnak a XIX. század elején. ${ }^{3}$ Philippe Lacoue-Labarthe Absolu littéraire címü könyvében a töredékesség három legfontosabb kritériumát határozta meg: a befejezetlenséget, a témája változatos és vegyes legyen,

3 Lásd Ginette Michaud, »Le fragment: trois paradoxes en guise d'ouverture«. In Lire le fragment: Transfert et théorie de la lecture chez Roland Barthes. Montréal: Hurtubise HMH, coll. »Brèches«, 1989, 13-66. 
és végül, hogy az alkotás egységes szerkezete a müvön kívül jöjjön létre az olvasó által. Mercier könyve megfelel Lacoue-Labarthe két kritériumának: témája változatos és vegyes, ráadásul szakít az olvasás hagyományos módjával is: az egyes szövegek között nincsen kohézió, azt a szöveg olvasója hozza létre (Lacoue-Labarthe-Nancy 1978, 60).

Összességében elmondhatjuk, Mercier Tableau de Paris címú mủve előfutára a XIX. század kószáló figurájának. A város gyors változásának a megragadása, és ennek bemutatásának igénye megelőlegezi a következő évek panorámairodalmát.

Több irodalomtörténész, nevezetesen Priscilla Parkhurst Ferguson (Ferguson 2015, 22-42), Karlheinz Stierle (Stierle 2001, 2) és Mary Gluck (Gluck 2003, 53-80) úgy látja, hogy a kószáló alakja egy jól behatárolható történelmi térben született meg a XIX. század első felében, Párizsban. Walter Benjamin is a nagyvárosi fejlődéssel, a passzázsok létrejöttével kapcsolja össze a XIX. századi sétáló megjelenését, ami szerinte gyökeresen megváltoztatta a városi ember észlelését (Crary 1999, 34). Georg Simmel is úgy gondolja, hogy a nagyvárosok nyüzsgése megváltoztatja a lakók érzékelését. Szerinte a nagyvárosi ember pszichológiáját meghatározza az idegi élet intenzívebbé válása, ami a gyors belső és külső benyomásokból fakad. Úgy gondolja, az ember egy differenciális lény, azaz a tudatát a pillanatnyi és az előző benyomások közötti különbség stimulálja. Így a tudatnak nagyobb szüksége van az állandó benyomások jelentéktelen különbségére, a menetük és az ellentétük szokásos egyenletességére, mint a gyorsan változó képekre, vagy a tekintet által érzékelt tárgyak közötti feltűnő eltérésre, vagy a benyomások váratlan jellemzőire (Simmel 1989, 234).

Walter Benjamin szerint is az észlelés kifejezetten idő- és mozgásfüggő. Úgy véli, hogy a modernitás megszünteti a szemlélődő nézőnek még a lehetőségét is, mert soha nincs tiszta hozzáférési útvonal egy tárgyhoz, és a látás mindig összetett. Minden tárgy más tárgyak, vágyak és vektorok melletti, és azokkal átfedésben lévő (Crary 1999, 34).

A megváltozott észlelésnek a következménye az ún. panorámairodalom, amelynek a narrátora a XIX. századi kószáló legkorábbi prototípusa. A panorámairodalom ${ }^{4}$ valójában nagyon vegyes szövegcsoportot foglal magába, és kiemelkednek közülük az ún. fiziológiák, amelyek a párizsi élet mindennapi embereit mutatják be a mozgó utcai árustól az opera előcsarnokában díszelgő ficsúrokig. Benjamin a panorámafestészettel köti össze ennek az irodalomnak a megjelenését. Szerinte, míg az építészet a vasszerkezettel, addig a festészet

4 Walter Banjamin adta ezt az összefoglaló nevet olyan szövegeknek, mint Le livre des Centet-un, Les Français peints par eux-mêmes, Le diable à Paris (Benjamin 1980, 850). 
a panorámával kezd kinőni a mủvészetből, és velük párhuzamosan megjelenik a panorámairodalom: a Les livres des Cent-et-Un (A Százegyek könyve) Les Français peints par eux-mêmes (A franciák, ahogy magukat festik), Le diable à Paris (Az ördög Párizsban), La grande ville (A nagyváros) sorolhatók ide.

A Paris ou le Livre des Cent-et-un müfajának a meghatározásában nincsen konszenzus a kollektív könyv szerzői között. Jules Janin müvében ,haszontalan esszének"5 nevezi írását, míg mások „vázlatnak” aposztrofálják, egyszerre utalva így a festészetre és a szövegek befejezetlenségére is. Walter Benjamin is különálló vázlatokként jellemzi ezeket a szövegeket, melyeknek anekdotaszerü előadásmódja mintha csak a panorámák plasztikus előterét utánozná. Zygmunt Bauman epizodikus szóval jellemzi a kószáló írásmódot. Szerinte a „sétálni menni” azt jelenti, hogy az emberi valóságot mint epizódok sorát próbáljuk végig, mint múlt és következmény nélküli eseményeket (Bauman 2004, 201).

Baudelaire maga is sétáló íróvá válik $A$ fájó Párizs címü kötetében. Ebben a müvében a francia nagyváros jelenségeit tematizálja prózaversek segítségével. Azzal, hogy a francia író összekapcsolja az írást és a kószálást, új kifejezési formára volt szüksége, amely alkalmas a sétáló fragmentáltan érzékelt tapasztalatának a leírásához. Az író a prózaverset érezte a legalkalmasabbnak ennek az élménynek a rögzítésére. Baudelaire erről így vall Arsène Houssaye-nak, a Presse föszerkesztőjének:

Ki az közülünk, aki nagyra törő napjaiban nem álmodott egy ütem és rím nélkül muzsikáló költői próza csodájáról, amely elég hajlékony és eléggé szaggatott, hogy hozzásimuljon a lélek lírai mozdulataihoz, a merengés hullámzásához, a tudat cikázásaihoz? Főképp a részvétel a nagyvárosok iszonyú forgatagában és keresztül-kasul szövődő, megszámlálhatatlan vonatkozásuk szüli ezt a zaklató ábrándot. ${ }^{6}$

Nemcsak a lírában, de a XIX. századi regényekben és novellákban is megjelenik a sétáló szemszögéből érzékelhető város. Philippe Hamon e leírásokban kétfajta nézőpontot különböztet meg (Hamon 1972, 468-469). Hagyományos formájuk, amikor egy mozdulatlan narrátor vagy szereplő szemszögéből látjuk a tájat vagy az utcarészletet. Ilyenkor egy szereplő vagy a narrátor könyököl, ül vagy áll, és letekint egy magaslatról. De az is előfordulhat, hogy séta közben

5 Jules Janin: L’Abbé Châtel et son église. In Paris ou le Livre des Cent-et-un t. II. 170. Idézi Marie Parmentier: Flâner, penser, écrire?: Questions sur la place de la littérature panoramique dans la généologie de l'essai (Farrugia-Loubier-Parmentier 2017, 134).

6 Charles Baudelaire-t idézi Walter Benjamin: A második császárság Párizsa Baudelaire-nél (Benjamin 1980, 891). 
megáll, hogy le tudja írni a körülötte lévő világot. Ez a fajta leírás nagyon gyakori Zola regényeiben, és ezzel magyarázható a sok nyitott ablak, ajtó, hall, üvegház, kirakat a naturalista írónál. Hamon a mozdulatlan nézőponttal szembeállítja a másik fajta leírást, amely során egy sétáló narrátor vagy szereplő szemszögéből látjuk a mozdulatlan tájat vagy utcarészletet. Úgy érzem, hogy az általa szembeállított kétfajta leírás nem áll szöges ellentétben egymással, és közöttük létezik néhány átmenet.

Balzac is sétáltatja szereplöit a városban, de nála még nem igazán beszélhetünk „mozgó leírásokról”. A realista francia író módszerét, amely már más XIX. századi regényekben is létezett, Debray-Genette „közelítő nézőpontnak” (perspective en approche) (Debray-Genette 1982, 289-344) nevezi. Ilyen leírással kezdődik a Goriot apó is. Itt a narrátor egy sétáló ember segítségével mutatja be Párizsnak ,a legvisszataszítóbb kerületét”7, ahol a Vauquer ház található. De amint elérkezünk a penzió bejáratához, a narrátor nézöpontot vált, és egy mozdulatlan szemszögből írja le a ház külsejét.

Robert Ricatte határozottan elkülöníti a „mozgó leírást” (description ambulatoire) a megálló és úgy körültekintő nézőponttól. Szerinte az előbbi nem hagyja magát megállítani egy dolognál, hanem átadja magát ,,a fél szemmel bizonytalanul látott dolgok káprázatának" (Ricatte 1953, 280). Ricatte szerint az első „mozgó leírást” Victor Hugo A nyomorultak címủ regénye második részének negyedik könyvében találhatjuk. ${ }^{8}$ Habár itt is „közelítő nézőponttal” van dolgunk, de a szüntelen mozgó nézőpontból érzékeljük a regény környezetét.

\footnotetext{
7 „A ház, amelyben a családi penzió virul, Vauquer-né tulajdona. Ott áll a Neuve-Sainte-Geneviève utca alsó részén, ahol a kövezet oly meredeken lejt az Arbalè utca felé, hogy lovas kocsival bajos közlekedni rajta. Ezért olyan csendesek a Val-de-Grâce-templom és a Panthéon közötti szük utcák. Ez a két műemlék megváltoztatja a környék légkörét, sárga tónusokat vet belé, és homályossá teszi kupolájának komor árnyékával. Itt száraz a kövezet, a lefolyókban se sár, se víz, a falak mentén fü burjánzik. Aki erre jár, lenne bár a leggondtalanabb ember, kedvét veszti itt; egy kocsi robogása errefelé esemény, a házak mogorvák, a falak börtönre emlékeztetnek. $A z$ erre vetödő párizsi csak polgári penziókat látna itt, vagy középületeket, nyomort vagy unalmat, haldokló öregséget, munkára kényszerülő vidám ifjúságot. Nincs Párizsnak visszataszítóbb kerülete, de mondjuk ki, ismeretlenebb sincs" (Kiemelések tőlem - B. M.) (Balzac 1983, 6-7).

8 „Negyven évvel ezelött a magányos sétáló, aki bemerészkedett a Salpêtrière elátkozott tájékára és a körúton át elment egészen az Italie sorompóig, olyan vidékre érkezett, ahol - bátran el lehet mondani - vége volt Párizsnak. Nem volt ez pusztaság, hiszen voltak járókelők; az utcákon olyan kerékvágások voltak, mint az országutakon és felverte őket a fü; nem is volt falu, ahhoz a házak túlságosan magasak voltak. [...] A lóvásártér ódon városnegyede volt ez. Ez a sétáló, ha ennek a lóvásártérnek düledező négy falán túl merészkedett, sőt ha rászánta magát, hogy túlmegy a Petit-Banquier utcán, miután jobboldalt elhagyott egy magas fallal kerített kertecskét, aztán egy rétet, amelyen cser kazlak emelkedtek, mint óriási hód-kunyhók, aztán egy bekerített telek mellett, amely teli volt ácsolt gerendával, tuskókkal, fürészporral és forgáccsal,
} 
Illyés Franciaországi változatok címü müvében elég kevés városleírással találkozhatunk, szemben az egy évvel korábbi Hunok Párisban címü önéletrajzi regénnyel, ahol a kószáló főszereplő-narrátor oldalakon keresztül írja le a francia fővárost. Viszont a kevés városleírás sétáló jellegü, sőt két fejezet tematizálja is a sétálást: egyik a Kószálás közben (Illyés 1974, 422-424), a másik pedig a Veszélyes séta (Illyés 1974, 318-320) címet viseli. Ez utóbbi fejezetben a narrátor az első párizsi sétája alkalmával tekint óvatosan jobbra-balra (Illyés 1974, 318), és örömmel fedezi fel a jól ismert épületeket:

Épp csak egy röpke pillantással söpröm végig a Szajna partját. A Mi Asszonyunk könnyed U-ja a második tekintetre is sértetlenül áll. Mintha törékeny üvegholmit érintenék, úgy illetem Szent Jakab fehér tornyát. Nem töri el az Eiffel sem. Oldódik rólam a gonosz varázslat. Megkönnyebbülök, lassan a régi természetességgel rakom a lábamat a földre (Illyés 1974, 318).

Egy hosszú kóborlást ír le az Árnyak között fejezet is, amelyben Illyés Orosz Anna után kutat, és elmegy régi lakásához. Megtudjuk, hol lakott Anna, és mely utcákon keresztül lehet eljutni oda a földalattiból kilépve. Mivel hajdani szerelme elköltözött, az író gyalog ereszkedik le a Szent Lajos-sziget felé, méghozzá kerülővel, és végigjárja a hajdani ismerős utcákat (Illyés 1974, 334). Később persze találkozik Orosz Annával, ami jó ürügy megint egy hosszú sétára. A Louvre-tól indulnak, majd a Louvre rakpart sarkán beülnek egy kávézóba beszélgetni (Illyés 1974, 380). A beszélgetés után átkelnek az Új Hídon, majd megállnak a Hôtel de Transsylvanie-vel szemben.

Egy másik rövid fejezete a münek a Városépités címü (Illyés 1974, 407), amely egy oldalt sem tesz ki, s szintén a narrátor utcai sétáját írja le. Amint át akar kelni a Soufflot utcán és a ,suhanó gépkocsik között”, eszébe jut, hogy Flaubert hőse, Moreau Frigyes pontosan innen nézte végig a Pantheon környéki tüntetést. Úgy gondolom, hogy Flaubert regényének említése nem véletlen, mert az Érzelmek iskolájában a francia író gyakran él a sétáló leírással. Másrészt ez a szövegrész felidézi a XIX. század második felében megszülető gondolatot, amellyel Walter Benjaminnál is találkozunk, hogy a város nemcsak egy valós tér, hanem szövegtér is. Benjamin szerint egy város sem kötődik annyira a könyvhöz, mint Párizs:

amelyeknek a tetején hatalmas kutya ugatott, aztán végigment egy düledező hosszú fal mellett, amelyet tavasszal felvert a virág, aztán pedig a legelhagyottabb helyen elment egy omladozó, szörnyü építmény előtt, amelyen nagy betủkkel ezt olvasta: HÍRDETÉSEK FELRAGASZTÁSA TILOS, akkor ez a vakmerő sétáló elért a Vignes-Saint-Marcel utca sarkára, erre a meglehetősen ismeretlen térségre" (Hugo 1959, 393). 
Girodux-nak igaza van, hogy az ember akkor a legszabadabb, ha kószálhat a Szajna mentén. A legtökéletesebb kószálás és ebből kifolyólag a legboldogabb, vezet a könyv felé, a könyvbe, mivel a Szajna rakpartjára tudós írások repkényei vannak odatapadva évszázadok óta: Párizs egy könyvtár nagy olvasóterme, amit átszel a Szajna (Benjamin 1998, 98).

Barthes a Walter Benjamin által megidézett városi szövegtérről pontosabban beszél. Szerinte is a város egy diskurzus, és ez a diskurzus nyelvnek tekinthető:

a város beszél a lakóihoz, beszéljük a városunkat, a várost, ahol élünk, már csak azáltal is, hogy ott lakunk, közlekedünk és nézzük. A város nyelve kifejezést azonban ki kell emelnünk egy olyan stádiumból, amely teljességgel metaforikusnak tekinthetö. Metaforikus értelemben, mint ahogy a film nyelvéről, vagy a virágok nyelvéről beszélünk, a város nyelvéról beszélni nem nehéz. Az igazi tudományos elörelépés azonban az lenne, ha úgy tudnánk a város nyelvéről beszélni, hogy közben nem használunk metaforát (Barthes 2005, 60).

Raymond Ledrut is a város szövegteréről beszél, amit elkülönít a nyelv önkényes jeleitől. Szerinte a városnak ún. természetes jelei vannak: „,belváros”, „út”, „tér”, „ez az út egy tér felé megy” stb.: „A város jelentéssel bír” (Ledrut 1986, 117). Ezt az elsődleges jelentést azonban Ledrut szerint kiegészíti egy másodlagos jelentés, ami szintén jelen van, felidéző hatalma van, és ,connotative semiocity"-ként emlegeti. Ez a másodlagos jellege a városnak lehet történeti, esztétikai és antropológiai természetú. A város jelentésének a két szintje közötti kapcsolat adja a város konnotatív szemiotikáját.

Illyés írásában a városi séták során gyakran idézi fel olvasmányélményeit, és így „rögtön kézből kapja a történelmet”: „Ott halt meg, nyomora végső stációjában, Wilde. Mintha - Bölöni könyve szerint - Ady is meglakta volna. A lekushadt város egyszerre emelkedni kezd" (Illyés 1974, 316). A város bizonyos részei nem csupán térben behatárolhatóak, hanem híres lakóikat is felidézik. A Flore kávéház a Szent Ármin és Benedek utca sarkán fekszik. A kávéház ma irodalmi központ, de Rimbaud-ék „hajdani találkozóhelye” (Illyés 1974, 354) is. A Saint-Germain negyedben, ,a nagypolgárság fellegvárában”; egy irodalmi szalonon is rátörnek olvasmányélményei, és Justh Zsigmond szemével tekint szét a csinos kis elöszobában (Illyés 1974, 426). A narrátor Ady Endre alakját idézi meg egy másik fejezetben is, amikor gyalog megy haza éjfél körül a Sebastión: „Ady korában [...], de még a mi korunkban is ilyen tájt szinte négyes sorokban, tömött hadrendben cirkáltak fel-alá a prostituáltak; férfinak kellett 
lennie a talpán, aki igazoltató gyürüikből kivágta magát. Most egy sincs. Hova tüntek? - találgatjuk.” Majd Illyés szomorúan konstatálja, hogy a Pigalle téren is a mulatók hajdani fellegvárai a „kihalt Ninivét idézik” (Illyés 1974, 332).

Ez utóbbi séta azért is érdekes, mert a kószálás fontos szabályát tematizálja. Ugyanis Louis Huart, a kószáló első leírója szerint: „Nem kószál, vagy nem tud kószálni, aki túl gyorsan megy - aki ásítozik az utcán - aki elhalad egy szép nő mellett anélkül, hogy megnézné" (Huart 1841, 120). Jelen esetben a sétálónk nem talál az utcán szép nőket, de valamilyen oknál fogva még a prostituáltak sem tartózkodnak kint.

Egy másik fejezet, Az üzem Poe $A$ tömeg embere címủ novelláját idézi fel, amely Walter Benjamin szerint a sétáló leírás egyik fontos müve (Benjamin 1980, 866-867). Az amerikai író novellájában a föszereplö éppúgy egy kávéházban ül, mint Illyés a Flore kávézóban, és nézegeti a vendégeket, kitalálva róluk történeteket. Azonban Illyéssel ellentétben Poe föhőse ezt megunja, és jobban leköti az utca képe a járókelőkkel. A magyar író ellenben megelégszik azzal, hogy számba veszi a kávézó híres íróit. Tőle néhány méterre RibemontDessaignes, a hajdani dadaista költö írogat, szemben vele Gorely, az orosz származású esztéta. A termecske túlsó falának tövében Sartre János regényíró neje, De Beauvoir Simonka ül, és veti a betüt szorgos odaadással: „nem csupán azért, mert maga is kitünő regényíró, hanem már azért, mert - ahogy minden irodalomban jártas embernek tudnia illik - ő naponta itt teremt, tekintettel arra, hogy az egyik szomszéd házban levő lakásukon férje költi müveit, s nem akarják zavarni egymást" (Illyés 1974, 356).

Majd kiderül az is, hogy Illyés bal oldali szomszédja Audiberti, és ,percegnek a tollak, suhannak a ceruzák, zörögnek és - ahogy átfordítják őket - suhognak a papírlapok" (Illyés 1974, 357). A dolgos munka persze rossz hatással van a magyar költőre, és szorongás szállja meg: „hogy dolgozatírási órán vagyok, rögtön felhangzik a folyosón a csengetés, csak én lopom az időt, s így el fogom veszíteni a tandíjmentességet, atyám kivesz az iskolából, sose lesz belőlem segédjegyző Dombóváron" (Illyés 1974, 359).

Mint már említettem, annak ellenére, hogy a Franciaországi változatok útirajz, viszonylag kevés városleírást tartalmaz. A szövegek sokkal inkább esszék, és a francia írókkal való találkozások, beszélgetések megörökítése. A narrátor általában az utazás élményéről beszél, Sartre két darabjáról, Európa egységéről, Herriot és Gide naplóiról, Miller Henrik - Illyés szerint - üres prózájáról, a magyar irodalom francia fordításairól és ismertségéről. De ezek az esszéisztikus részek csak látszólag térnek el a sétáló leírásoktól. Úgy gondolom, 
hogy ezek a kulturális kitérők nem különböznek a városban való kószálástól. Montaigne Esszéiben már használja a „vagabondage” szót, hogy jellemezze saját írásmódját. Ez a szó egyaránt jelent csavargást és csapongást. A magyar fordító az utóbbi szóval fordította: „Megfontolatlanul és rendületlenül váltok témát. Tollam és szellemem egyaránt csapong” (Montaigne 2013, 235).

Az útleírás és az esszé müfaja az irodalomtudósok szerint sem áll messze egymástól. Hugo Friedrich könyvében rámutatott arra, hogy Montaigne Esszéi kapcsolatba hozhatók a sétálással. Tanulmányának kulcsfogalma a „szabad mozgás": a séta, a csavargás közben a szellem szabad, és számtalan benyomás éri, és váratlan gondolatok jutnak eszébe (Friedrich 1968, 348-349). Graham Good az esszéket tipologizáló tanulmányában az egyik fajta esszét „utazásesszé"-nek (travel essay) nevezi. Kommentárjában azonban kibővíti ezt a kategóriát, és összeveti az útleírást az „utazás-esszé”-vel. Míg az előbbi szerinte egy teljes utazásról ad számot, és bemutat egy egész kontinenst vagy régiót, addig az „utazás-esszé” csak egy sétáról, egy kirándulásról számol be. Sőt, az is elmondható, hogy az esszé csak ürügye a helyváltoztatásnak, amely kószáláshoz, csavargáshoz vezet, azaz cél nélküli utazáshoz. Graham Good szerint ilyenkor a bejárt vidék, a táj egy nem tudatos utazás következménye. Good úgy gondolja, hogy minden esszé ilyen módon épül fel: „Bizonyos szempontból az esszé vándorló, sétáló forma. Elegye az önmagunkkal való foglalkozásnak és a megfigyelésnek, lehetőség a látnivalókra, találkozás a helyváltoztatással, az irányokkal, célokkal, a sétálás az esszéírással analóg tevékenység" (Good 1988, XII). Michel Beaujour összehasonlítva Montaigne Esszéit és Rousseau Egy magányos sétáló álmodozásait arra a következtetésre jut, hogy mind az esszé, mind a sétálás utánozza a szellem csapongását, és semmi más nem fontos nekik, csak az, hogy hüségesen kövessék a lélek, a szellem és a test mozgását (Beaujour 1980, 66).

Ez a rövid összefoglaló is érzékeltette, hogy milyen közel áll egymáshoz a sétáló és az esszéíró. Ráadásul úgy gondolom, hogy mindkettő egy töredékes világot közvetít. Míg a sétáló átadja magát a mozgalmas város vizsgálatának, „szétszórt morzsákat gyüjt” (Montandon 2000, 154). Az esszé is törésekben gondolkodik, mint ahogy a valóság is töredezett, és egységét a töréseken keresztül találja meg, nem pedig abban, hogy elsimítja azokat. Adorno szerint a logikai rend egyszólamúsága félrevezet: „elfedi az antagonisztikus lényegét annak, amit ráhúztak. Az esszé számára a diszkontinuitás a lényeges, hiszen állandóan egy ideiglenesen lecsendesített konfliktussal van dolga" (Adorno 1998, 41). Úgy gondoljuk, a Franciaországi változatok rövid fejezetei és a közöttük lévő fehér részek, szünetek is ezt a töredezettséget vizualizálják. 
Összegzésként elmondhatjuk, hogy Illyés a Franciaországi változatokban sétálóként egyrészt a város utcáit rója, másrészt esszéiben a francia kultúra fontos kérdéseit járja körül. Úgy gondolom, hogy a két kószálásban van egy közös pont. Mindkét séta során megőrzi a kívülálló pozícióját. A sétáló, mint ahogy Baudelaire is írta, ,független, lázas, pártatlan szellem” (Baudelaire 1977, 307). A francia költő szerint olyan fejedelem, ,aki mindenütt megőrzi inkognitóját" (Benjamin 1980, 857). A kószáló, habár a tömeg része, de távolságtartása és láthatatlansága révén kívül tud maradni a város forgatagán. A kószáló megőrzi anonimitását a tömegben, mindent megfigyel, ellenben ő soha nem válik a megfigyelés tárgyává. A kószálót azonban nem szabad összetéveszteni a bámészkodóval, mert előbbi mindig teljesen megőrzi egyéniségét, a bámészkodó viszont elveszíti: „Teljesen feloldódik a külvilágban, annyira elkábul tőle, hogy elfeledkezik saját magáról. Az elébe táruló színjáték hatására a bámészkodó személytelen lénnyé válik, nem is ember többé: közönség lesz belőle, tömeg." A kószáló odatartozó és a kívülálló érzéséről, ami megkülönbözteti a bámészkodótól, Robert Wilson így írt: ,a világ álomszerüvé válik; én magam [...] valaminek a belseje leszek... Többé nem saját magam vagyok, hanem másvalaki, de pont ezért inkább magam vagyok" (Walser 1987, 85).

Illyés esszéiben is megőrzi a kívülálló pozícióját, hiszen az esszéisztikus betétek gyakran egy keletről, Magyarországról jött ember szemszögéből járják körbe az írói etikai kérdéseket, Európa helyzetét stb. Ugyanazt a kettős arculatú képet vélem felfedezni a Franciaországi változatok címü múvének a szövegmorzsáiban, amiről Szegedy-Maszák Mihály beszél Illyés és a francia irodalom címú írásában: egyrészt kisebbségi érzés töltötte el a francia kultúrával szemben, másfelől a magyar irodalom jelentőségének a bizonyítására törekedett (Szegedy-Maszák 2007, 405).

Összességében elmondhatjuk, hogy a sétáló „esztétikája” átjárja Illyés müvét. Sokan megvádolták a korszak kritikusai közül, hogy mủve a háború utáni Párizst felületesen mutatja be. Keszi Imre a Szabad Népben erről így ír: „nem nyúl a problémák legmélyére, a mozgalmas párisi élet mögött nem látja meg, vagy legalábbis nem tárja fel a lappangó és időnként fel-feltörö belső erőket" (Keszi 1947, 4). A kritikusokkal ellentétben úgy gondolom, hogy Illyés nem is akarta fotografikusan pontos képét adni a városnak. Nem akarja visszaadni szociológiailag komplex társadalmát a háború utáni Párizsnak. A mü nemcsak tartalmi szinten, hanem formájában is színpadra állítja a sétálás aktusát.

\footnotetext{
9 Victor Fournel, Ce qu'on voit dans les rues de Paris, Paris, 1858, idézi Walter Benjamin: A második császárság Párizsa Baudelaire-nél (Benjamin 1980, 892).
} 


\section{Irodalom}

Adorno, Theodor W. 1998. Az esszé mint forma. Ford. Hegyessy Mária. In A müvészet és a müvészetek: Irodalmi és zenei tanulmányok. 29-47. Budapest: Helikon.

Balzac, Honoré de. 1983. Goriot apó. Ford. Lányi Viktor. Budapest: Európa.

Barthes, Roland. 2005. Szemiológia és városkutatás. Ford. Schneller Dóra. 200017 (4): 57-66.

Baudelaire, Charles. 1977. A modern élet festője. Ford. Csorba Géza. In Ima az Akropoliszon: A francia esszé klasszikusai, vál. Gyergyai Albert. 297-315. Budapest: Európa.

Bauman, Zybmunt. 2004. A zarándok és leszármazottai: sétálók, csavargók és turisták. Ford. Teller Katalin. In Az idegen: Variációk Simmeltől Derridáig, szerk. Biczó Gábor. 192-206. Debrecen: Csokonai.

Beaujour, Michel. 1980. Miroirs d'encre: Rhétorique de l'autoportrait. Paris: Seuil.

Benjamin, Walter. 1969. Párizs, a XIX. század fővárosa. Ford. Széll Jenő. In Kommentár és prófécia. 75-94. Budapest: Gondolat Kiadó.

Benjamin, Walter. 1980. A második császárság Párizsa Baudelaire-nél. Ford. Bence György. In Angelus Novus: Értekezések, kísérletek, bírálatok. 819-933. Budapest: Magyar Helikon.

Benjamin, Walter. 1998. Images de pensée. Ford. Jean-François Poirier. Paris: Christian Bourgois Éditeur.

Crary, Jonathan. 1999. A megfigyelö módszerei. Ford. Lukács Ágnes. Budapest: Osiris Kiadó.

Debray-Genette, Raymonde. 1982. Traversée de l'espace descriptif. Poétique 13 (51): 289-344.

Delon, Michel. 1990. Piétons de Paris. Préface générale à Louis Sébastien Mercier et Rétif de la Bretonne. In Paris le jour, Paris la nuit. I-XXIV. Paris: Robert Laffont.

Farrugia, Guilhem-Loubier, Pierre-Parmentier, Marie vál. és szerk. 2017. Promenade et flânerie: Vers une poétique de l'essai entre les XVIII et XIX ${ }^{e}$ siècles. Rennes: Presses universitaires de Rennes.

Ferguson, Priscilla Parkhurst. 1993. The Flaneur and the Production of Culture. In Cultural Participation: Trends Since the Middle Ages, szerk. Rigney, Ann-Fokkema, Douwe W. 109-124. Amsterdam-Philadelphia: John Benjamins Publishing.

Ferguson, Priscilla Parkhurst. 1994. Paris as revolution. Berkeley-Los Angeles-London: University of California Press.

Ferguson, Priscilla Parkhurst. 2015. The flâneur on and off the streets of Paris. In The flâneur, szerk. Keith Tester. 22-42. London-New York: Routledge.

Fiers Tamás. 1947. Franciaországi változatok (Nyugat). Új Szántás 1 (6): 375-376.

Friedrich, Hugo. 1968. Montaigne. Ford. Robert Rovini. Paris: Gallimard. 
Gleber, Anke. 1999. The Art of Taking a Walk. Princeton-New Jersey: Princeton University Press.

Gluck, Mary. 2003. The Flâneur and the Aesthetic: Appropriation of Urban Culture in Mid-19 $9^{\text {th }}$ - Century Paris. Theory, Culture \& Society 20 (5): 53-80.

Good, Graham. 1988. The Observing Self: Rediscovery of the Essay. London: Routledge. Hamon, Philippe. 1972. Qu'est-ce qu'une description? Poétique 3 (12): 465-485.

Huart, Louis. 1841. Physiologie du flâneur. Paris: Aubert.

Hugo, Victor. 1959. A nyomorultak 1. Ford. Lányi Viktor-Révay József. Budapest: Európa.

Illyés Gyula. 1974. Franciaországi változatok. In Szíves kalauz. 295-452. Budapest: Szépirodalmi.

Keszi Imre. 1947. Illyés Gyula: Franciaországi változatok. Szabad Nép, jún. 12. 130. 4.

Lacoue-Labarthe, Philippe-Nancy, Jean-Luc. 1978 L'exigence fragmentaire dans l'Absolu littéraire: Théorie de la littérature du romantisme allemand. Paris: Seuil.

Ledrut, Raymond. 1986. Speech and Silence of the City. In The City and the Sign: An Introduction to Urban Semiotics. Kiad. M. Gottdiener, Alexandros Lagopoulos. 114-134. New York: Columbia University Press.

Mazlish, Bruce. 2015. The flâneur on and off the streets of Paris. In The flâneur, szerk. Keith Tester 43-60. London-New York: Routledge.

Mericer, Louis Sébastien. 1994. Tableau de Paris: 1-2. Paris: Mercure de France.

Montaigne, Michel de. 2013. Esszék 3. Ford. Csordás Gábor. Pécs: Jelenkor.

Montandon, Alain. 2000. Sociopoétique de la promenade. Clermond-Ferrand: Presses Universitaires Blaise Pascal-Maison de la Recherche.

Németh Ákos. 2015. „,Vigasztalásul útnak indulunk... ”: A „, vándorévek” nemzedéke és a két világháború közötti magyar útirajz-hagyomány. Doktori értekezés. Pécs: Pécsi Tudományegyetem, Bölcsészettudományi Kar.

Ricatte, Robert. 1953. La Création romanesque chez les Goncourt 1851-1870. Paris: Armand Colin.

Simmel, Georg. 1989. Philosophie de la modernité: La femme, la ville, l’individualisme. Ford. Jean-Louis Vieillard-Baron, Paris: Payot.

Stalnaker, Joanna. 2006. The New Paris in Guise of the Old. Louis Sébastien Mercier from Old Regime to Revolution. Studies in Eighteenth Century Culture (35): 223-242.

Stierle, Karlheinz. 2001. La Capitale des signes: Paris et son discours. Ford. RocherJacquin, Marianne. Paris: Editions de la Maison des Sciences de l'Homme.

Szegedy-Maszák Mihály. 2007. Illyés és a francia irodalom. In A magyar irodalom történetei: 1920-tól napjainkig, szerk. Szegedy-Maszák Mihály-Veres András. 403-417. Budapest: Gondolat.

Walser, Robert. 1987. La promenade. Ford. B. Lortholory. Paris: Gallimard. 


\title{
ACCOUNT OF A HUNGARIAN WANDERER'S JOURNEY IN FRANCE
}

\author{
Fragmentariness and mosaic features in the work
} French Variations by Gyula Illyés

In 1947 Gyula Illyés went to France twice. He spent five weeks in Paris at the beginning of the year, and then travelled to southern France in November. He recorded his two journeys in a travelogue. This study deals with his days in Paris written about in his work Franciaországi változatok (French Variations). The characteristics of this travelogue is that it is a collection of texts of various styles and mosaic-like features: it mixes essays and actual travel descriptions, most of it are strolling around descriptions. The structure of the work's timeline is also intermittent, and there are many ellipses and omissions at the time of narration. The entire travelogue is imbued by the aesthetic of a wanderer. Descriptions and figures of strollers became popular in the 19th century when a new "landscape", that of the city, appeared. Illyés' work is not simply strolling descriptions, but the fragmentariness of the work's form, even with the interruptions and omissions, visualises strolling. Thus, the work sets the stage for the act of walking not only on the content level but also in its form. Keywords: Gyula Illyés, France, wanderer, essay, discontinuity, fragmentariness

\section{PUTOPIS PO FRANCUSKOJ JEDNOG MAĐARA, LUTALICE Fragmentarnost $i$ mozaičnost u delu Francuske varijante Đule Ileša}

Đula Ileš je 1947. godine bio dva puta u Francuskoj. Početkom godine proveo je pet nedelja u Parizu, zatim je u novembru otputovao na jug zemlje. Oba putovanja je ovekovečio u svojim putopisima. Predmet rada je pariski boravak opisan u delu Francuske varijante. Specifičnost ovog putopisa je u tome što predstavlja zbirku mozaičkih tekstova pisanih različitim stilovima: mešaju se eseji sa opisima mesta i događaja na putu, od kojih većinu čine opisi šetnji. I vremenska struktura dela je isprekidana. U pripovedanju ima dosta elipsi i izostavljenih delova. Putopis prožima motiv lutalaštva. Opis šetnji i figura šetača je postala popularna u XIX veku kada grad postaje novi „krajolik“ kao predmet opisa. U Ilešovom delu osim opisa šetnji nalazimo i prikaz šetnje u fragmentiranoj formi i sa izostavljenim delovima. Time se akt šetnje predstavlja kroz dva nivoa, sadržinski i formalno.

Ključne reči: Đula Ileš, Francuska, lutalica, esej, diskontinuitet, fragmentarnost 